\title{
Efficacy of insect-proof nets used in Tunisian tomato greenhouses against Tuta absoluta (Meyrick) (Lepidoptera: Gelechiidae) and potential impact on plant growth and fruit quality
}

\author{
A. Harbi, ${ }^{1}$ K. Abbes, ${ }^{1}$ B. Dridi-Almohandes, ${ }^{2}$ B. Chermiti ${ }^{1}$ \\ ${ }^{1}$ Laboratory of Entomology and Biological control, Department of Plant Protection; ${ }^{2}$ Conventional \\ and Organic Vegetable Crops Unit, High Agronomic Institute of Chott-Mériem, University of Sousse, \\ Tunisia
}

\begin{abstract}
Insect-proof screens constitute efficient physical means of protecting horticultural crops against insect pests and their use has become widespread. However, they may have a negative impact on plant growth and fruit quality by modifying climatic parameters of greenhouses. In case of tomato crops, they are used mainly against white flies and the tomato leaf miner Tuta absoluta (Meyrick). In Tunisia, tomato plastic tunnels are often netted following two modalities: i) complete netting of the greenhouse under the plastic screen (total netting); or ii) netting only doors and lateral aeration windows (partial netting). Weekly monitoring of $T$. absoluta in two tomato greenhouses with different netting setups using pheromone traps and sampling of leaves and fruits showed no differences in the levels of infestation by the pest with a maximum average values of 6.66 eggs/leaf, 4.16 larvae/leaf and 4.16 mines/leaf. The maximum infestation rate of leaves was $86.66 \%$ and that of fruits was $10.83 \%$. No effects of the net-
\end{abstract}

Correspondence: Brahim Chermiti, Laboratory of Entomology and Biological control, Department of Plant Protection, High Agronomic Institute of ChottMériem, Chott-Mériem 4042, University of Sousse, Tunisia.

Tel.: +216.28156148.

E-mail: chermiti54@yahoo.fr

Key words: Climatic parameters; leafminer; physical barrier; sugar contents.

Acknowledgements: the authors wish to thank Rabeb Fersi for her technical assistance during the experiments. We also wish to acknowledge the valuable comments from anonymous reviewers that substantially improved the quality of the paper.

Received for publication: 27 April 2015.

Revision received: 4 August 2015.

Accepted for publication: 4 Agust 2015.

(ㄷ) Copyright A. Harbi et al., 2015

Licensee PAGEPress, Italy

Journal of Entomological and Acarological Research 2015; $47: 5256$

doi:10.4081/jear.2015.5256

This article is distributed under the terms of the Creative Commons Attribution Noncommercial License (by-nc 3.0) which permits any noncommercial use, distribution, and reproduction in any medium, provided the original author(s) and source are credited. ting setup used on plant growth parameters were detected. However, the study of fruit quality parameters revealed significant decrease in sugar contents in tomato fruits when using total netting setup ( $4.26^{\circ}$ Brix versus $3.68^{\circ}$ Brix). Recommendations regarding the combined use of pheromones traps and insect-proof nets are given and possibilities to enhance the efficiency of nets as physical barrier against T. absoluta are explored.

\section{Introduction}

The tomato leafminer Tuta absoluta (Meyrick) (Lepidoptera: Gelechiidae) is ranked among the most devastating insect pests of Mediterranean open field and greenhouse tomato cultivations (Desneux et al., 2010, 2011; Lebdi et al., 2011; Abbes et al., 2012b). Originating from South America, this moth invaded the Mediterranean region since 2006 through Spain (Urbaneja et al., 2007; Desneux et al., 2010). Currently, the pest continues its spread through Asia and subSaharan Africa (Desneux et al., 2011; Brévault et al., 2014). T. absoluta has a high reproductive fitness as it can complete up to 12 generations per year depending on climatic conditions (Tropea Garzia et al., 2012). Damage is caused by the mining larvae attacking leaves, stems and fruits and losses can reach up to 100\% (Guenaoui, 2008; Chermiti et al., 2009; Tropea Garzia et al., 2012). Besides, this pest has been reported to develop resistance to many commonly sprayed insecticides (Siqueira et al., 2001; Guedes \& Picanço, 2012; Haddi et al., 2012; Roditakis et al., 2015). Furthermore, it has been lately demonstrated that females of some populations of T. absoluta from France and Tunisia are able to reproduce parthenogenetically in the laboratory which may make its management difficult task (Megido et al., 2012, 2013a; Abbes \& Chermiti, 2014).

Several control tactics have been developed and integrated in pest management schemes targeting this economic pest including male annihilation using sex pheromone traps, mating disruption and biological control mainly through the use of mirid bugs (Mollá et al., 2011; Lebdi et al., 2011; Abbes et al., 2012a, 2012b; Cocco et al., 2013; Megido et al., 2013b). In Tunisian unheated tomato plastic tunnels, the control strategy based principally on the use of the male monitoring of this pest has been supported by the use of insect-proof nets to avoid the migration of gravid females from the outside and the re-infestations of the pheromone-treated crops (Abbes et al., 2012b).

Physical barriers have been used in horticulture as reliable and efficient tools to protect tomato cultivations and nurseries from several key insect pests such as thrips, white flies and T. absoluta (Castellano et al., 2008; Harbi et al., 2012). Nevertheless, they may have a negative effect 
on plant growth and fruit quality by modifying climatic parameters of greenhouses (Teitel, 2006; Valera et al., 2006). In the Mediterranean region, unheated plastic tomato tunnels protected with insect proof nets have been frequently infested by $T$. absoluta especially near the openings leading to extensive insecticide applications (Abbes \& Chermiti, 2011; Harbi et al., 2012; Cocco et al., 2013; Biondi et al., 2015). This can eventually increase the possibilities of insecticide resistance in T. absoluta populations. Furthermore, many insecticides used against T. absoluta have been reported as not compatible with the natural enemies used for the biological control of this pest owing their possible acute and long term toxicological side effects on non target arthropods (Carvalho et al., 2003; Biondi et al., 2012a, 2012b, 2013).

In Tunisia, two setups of insect proof nets are commonly used in tomato tunnels: i) some growers prefer to completely cover the plastic tunnels with insect-proof net and to overlay the plastic film to ensure hermetic isolation of the greenhouse from the external environment and to reduce the entrance of T. absoluta gravid females; or ii) some others prefer to put the insect proof net only in the aeration windows and doors which is a more economical option. This study was carried out aiming to: i) evaluate the efficacy of these two insect-proof net setups to control T. absoluta in greenhouses when combined with male monitoring; ii) assess possible impacts of both netting setups on plant growth and quality parameters of tomato fruits. The efficiency of netting strategies is discussed and recommendations for a better control of T. absoluta using insect-proof nets are given.

\section{Materials and methods}

\section{Experimental greenhouses}

The study was conducted in two tomato greenhouses located in the region of Bekalta (Tunisian Central Coast). Tomato plants of the cultivar Sahel were grown from seeds in a pest free nursery and transplanted on $10^{\text {th }}$ November 2009 with a density of 3 plants $/ \mathrm{m}^{2}$. Experimental greenhouses were $64 \mathrm{~m}$ long, $8.5 \mathrm{~m}$ wide and $3 \mathrm{~m}$ high. They were protected with white-coloured insect-proof net of $6 \times 8$ threads $/ \mathrm{cm}^{2}$ and covered with plastic screens. The first greenhouse (hereafter called $T$ ) was completely covered with insect-proof screen and with polyethylene plastic with three aeration strips $1.5 \mathrm{~m}$ large each spaced out by $19.8 \mathrm{~m}$. Conversely the second greenhouse (hereafter named $P$ ) was covered with polyethylene plastic film and insect-proof screens were installed only in the three aeration strips of the same size of greenhouse $T$. In both greenhouses, the resulting aeration rate was of $13.7 \%$.

\section{Male monitoring}

In addition to insect-proof nets, the adult population dynamics were monitored by placing in each greenhouse one sex pheromone water trap (Tutasun ${ }^{\circledR}$, Koppert Biological Systems, The Netherlands). Traps were installed on $11^{\text {th }}$ December 2009 at $40 \mathrm{~cm}$ height from the ground level in the centre of greenhouses. Sex pheromone lures (Pherodis ${ }^{\circledR}$, Koppert Biological Systems) loaded with $0.5 \mathrm{mg}$ of synthetic sex pheromone of T. absoluta and they were renewed every five to six weeks. Trapped males were monitored every week and the level of water in the traps was adjusted as needed.

\section{Insecticide treatments}

As a part of the integrated pest management scheme against $T$. absoluta, the experimental crops were sprayed with a Bacillus thuriengiensis var. kurstaki based insecticide (Bactospeine 16000, Valent BioSciences Corp., USA). Sprays were based on the level of male weekly catches of the moth in the pheromone traps with a threshold of 30 males/trap/week (Megido et al., 2013b). Sprays were performed on $9^{\text {th }}$ February, $3^{\text {rd }}$ March $2010,7^{\text {th }}$ and $30^{\text {th }}$ April and $10^{\text {th }}$, $15^{\text {th }}$ and $17^{\text {th }}$ May 2010.

\section{Sampling}

The assessment of the preimaginal populations of T. absoluta in both greenhouses was carried out from 20 $0^{\text {th }}$ December 2009 to $2^{\text {nd }}$ June 2010 through random sampling of leaves as described by Gravena (1991) for leafminers and leaf borers. The sampling protocol consists on the examination of the first fully developed leaf from the upper third of tomato plants; since young leaves are the preferential oviposition site for T. absoluta (Silva et al., 1998; Leite et al., 1999). For each greenhouse, 30 fully developed leaves were collected weekly from the upper part of the tomato plant and the number of all present instars of the tomato leafminer was counted in laboratory using a Leica MS5 stereomicroscope (Leica, Germany). The infestation rate of fruits per plant was assessed weekly by counting infested and total number of fruits directly 20 tomato plants randomly chosen in each studied greenhouse.

Air temperature and air relative humidity were monitored in both greenhouses using data loggers Type Watch Dog ${ }^{\circledR}$ (Spectrum Technologies, USA).

\section{Assessment of plant growth and quality parameters of tomato fruits}

To compare the impact of the netting setup on tomato plant growth, 12 plants were randomly chosen in each greenhouse. The growth parameters were measured weekly starting with day 100 and continuing to day 142 after transplanting. The investigated parameters were: plant height, stem diameter at $30 \mathrm{~cm}$ from the apex and height of the first fruit cluster.

The study of quality parameters in the tomato crops was based on fruit sampling in four ripening stages (S1: turning, S2: pink, S3: lightred, and S4: red-ripe). Thirty fruits for each ripening stage were randomly chosen in three different dates for each greenhouse. The identification of the ripening stages of tomatoes was based on external fruit colour (Viskelis et al., 2008).

The considered fruit quality parameters were weight, firmness, $\mathrm{pH}$, total soluble solid (TSS), acidity and dry matter. The weight of sampled fruits was determined with a precision electronic scale type Sartorius Basic ${ }^{\circledR}$ model B 120S (Sartorius, Germany). To assess the firmness of fruits, a flat headed stainless steel cylindrical probe of $2 \mathrm{~mm}$ in diameter was used. Penetration test started when the probe got in contact with tomato surface, and finished when the probe penetrated the tissue to a depth of $8 \mathrm{~mm}$. Probe speed during penetration test was $1 \mathrm{~mm} / \mathrm{s}$. Thirty tomatoes of each ripening stage were tested in two opposite locations in the middle of the fruit. On the other hand, during the cropping cycle, three measures of $\mathrm{pH}$ were performed for each ripening stage of tomato fruits at 128, 135 and 142 days after transplanting. Ten homogeneous fruits per ripening stage per date were homogenised and $\mathrm{pH}$ was measured with a Jenway ${ }^{\circledR}$ digital pH-metre model 3505 (Jenway, UK). Three replicates per ripening stage and per date were performed. Regarding TSS, three measures were taken at 128, 135 and 142 days after transplanting on ten homogeneous fruits for every ripening stage using an Atago ${ }^{\circledR}$ digital refractometer Model DR-M2 (Atago, France). For each date, measurements were replicated three times. The titrable acidity (TA) was determined by titration of the compost powder sample homogenised with $0,01 \mathrm{~N} \mathrm{NaOH}$ using phenolphthaleinindicator (expressed as $\mathrm{g} / \mathrm{L}$ of citric acid) (Caliman et al., 2010). The titration was replicated three times per ripening stage and per date. Finally, the dry matter was calculated for each sampled tomato fruit from the weight difference before and after oven drying of ten fruits at $70^{\circ} \mathrm{C}$ during $72 \mathrm{~h}$ (Wuzhong, 2002). 


\section{Statistical analysis}

The mean density of eggs and larvae on leave and the infestation rates of leaves and fruits as well as mean values of the plant growth parameters (plant height, stem diameter at $30 \mathrm{~cm}$ from the apex and the height of the first fruit cluster) and fruit quality parameters (weight, firmness, pH, TSS, acidity and dry matter) were compared using Student's $t$ test at the significance level of 5\% using the statistical software SPSS (Statistical Package for the Social Sciences, version 17.0).

\section{Results}

\section{Climatic parameters}

In the greenhouse $T$, the average temperature ranged from $11.6^{\circ} \mathrm{C}$ recorded on $17^{\text {th }}$ February 2010 to $24.1^{\circ} \mathrm{C}$ on $2^{\text {nd }}$ June 2010 (Figure 1A). The lowest minimum temperature was registered on $13^{\text {th }}$ January 2010 $\left(1.4^{\circ} \mathrm{C}\right)$ whereas the highest was $43.5^{\circ} \mathrm{C}$ registered on $2^{\text {nd }}$ June 2010 . With regards to relative humidity ( $\mathrm{RH})$ (Figure 1B), average values were between $59 \%$ recorded on $6^{\text {th }}$ January 2010 and $87.4 \%$ on $10^{\text {th }}$ March 2010.

In the greenhouse $P$, the average temperature ranged between $12.2^{\circ} \mathrm{C}$ and $23.6^{\circ} \mathrm{C}$ recorded on $17^{\text {th }}$ February 2010 and $2^{\text {nd }}$ June 2010 , respectively. The lowest minimum temperature was $2.7^{\circ} \mathrm{C}$ recorded on $9^{\text {th }}$ February 2010 while the highest was $39.3^{\circ} \mathrm{C}$ on $2^{\text {nd }}$ June 2010 (Figure 2A).

The average RH was between $48.6 \%$ recorded on $6^{\text {th }}$ January 2010 and raised to $84.6 \%$ n 102010 with a minimum of $20.7 \%$ observed in January and a maximum of $100 \%$ during February, March and April (Figure 2B).

\section{Male monitoring}

The monitoring of the imaginal population of T. absoluta in greenhouse $T$ showed a low population density from the beginning of the study towards $7^{\text {th }}$ April 2010 during which the number of captured adults per trap and per week was relatively low and peaked at 75 males in on $3^{\text {rd }}$ March 2010. Starting from $7^{\text {th }}$ April 2010, the number of caught males increased progressively to reach a maximum of 207 males trapped on $21^{\text {st }}$ April 2010. After that, capture decreased to values ranging from 97 to 138 individuals per trap per week towards the end of the cropping cycle.

Similar flight pattern was observed in greenhouse $P$ starting with low trap catches from the beginning of the trial until $4^{\text {th }}$ April 2010 when 58 individuals/trap/week were recorded (Figure 3B). The number of captured males increased gradually to reach a maximum of 296 males per trap per week on $12^{\text {th }}$ May 2010 and thereby decreasing at the end of the cultivation owing the end of the cropping cycle and the absence of young leaves, preferential oviposition site for T. absoluta.
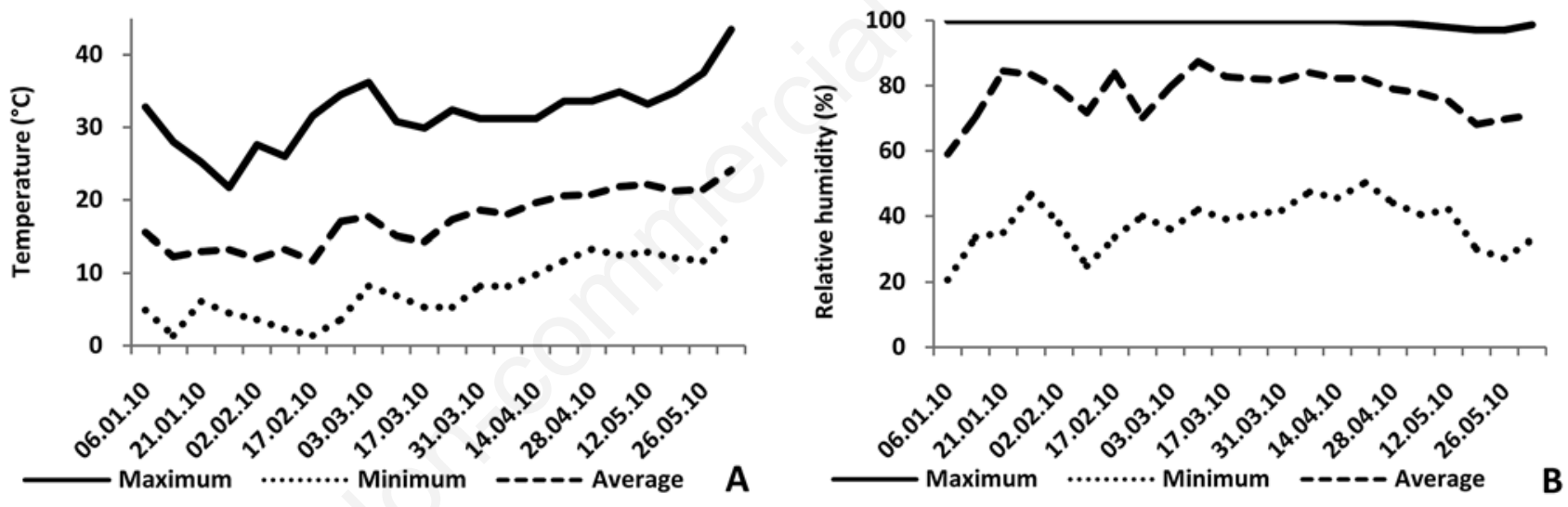

Figure 1. Maximum, minimum and average daily temperature (A) and relative humidity (B) in the greenhouse $T$ during the study.
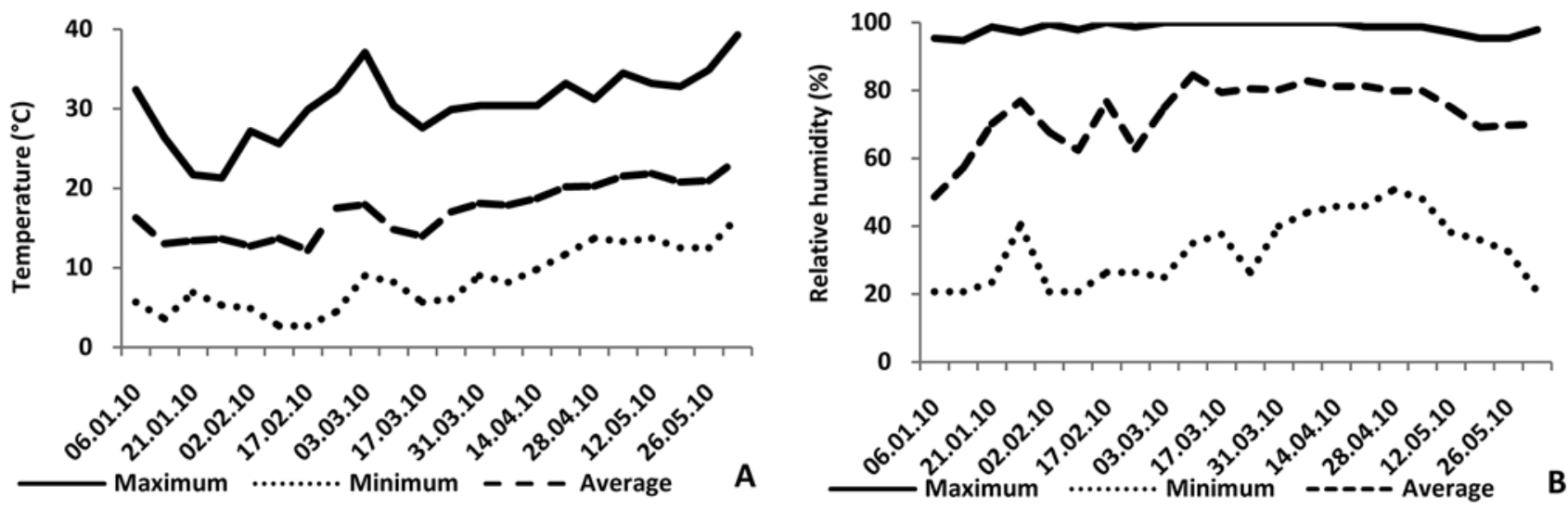

Figure 2. Maximum, minimum and average daily temperature (A) and relative humidity $(B)$ registered in the greenhouse $P$ during the study. 
Population dynamics and infestation parameters on leaves

The assessment of the population dynamics of $T$. absoluta in greenhouses $T$ and $P$ revealed the absence of all biological instars of the insect during the beginning of the trial until $14^{\text {th }}$ April 2010 in greenhouse $T$ and $21^{\text {st }}$ April 2010in greenhouse $P$ (Figure 4). The low population density until April is confirmed by the absence of mines and a low infestation rate on leaves not exceeding $3.3 \%$ in greenhouse $T$ and $10 \%$ in greenhouse $P$ (Figure 5). The population density increased
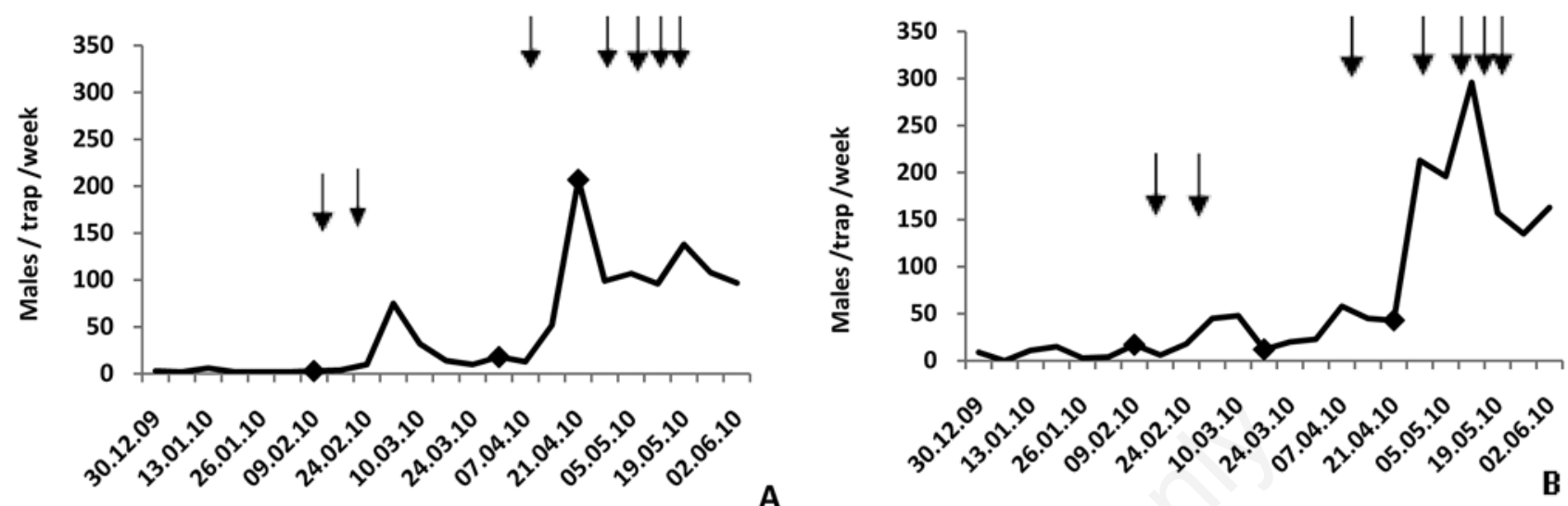

Figure 3. Tuta absoluta male capture in pheromone traps in greenhouses $T(\mathrm{~A})$ and $P(\mathrm{~B}) .(\diamond)$ indicates lure renewal and $(\downarrow)$ indicates Bt sprays.

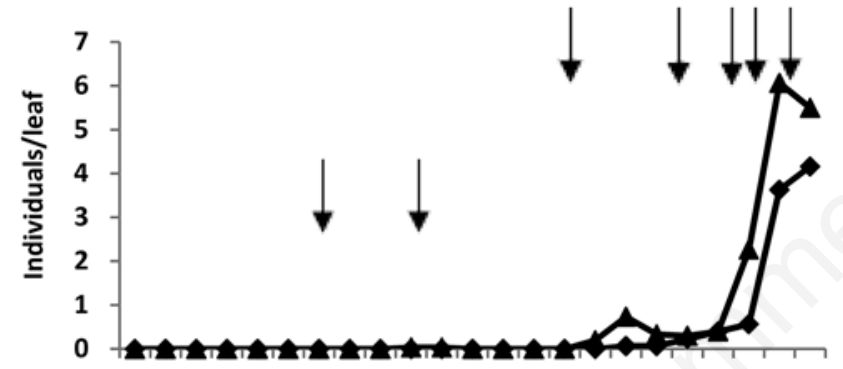

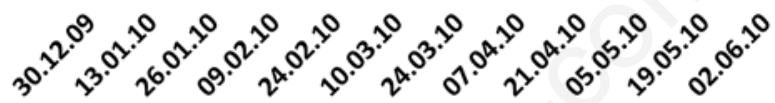

- eggs

A
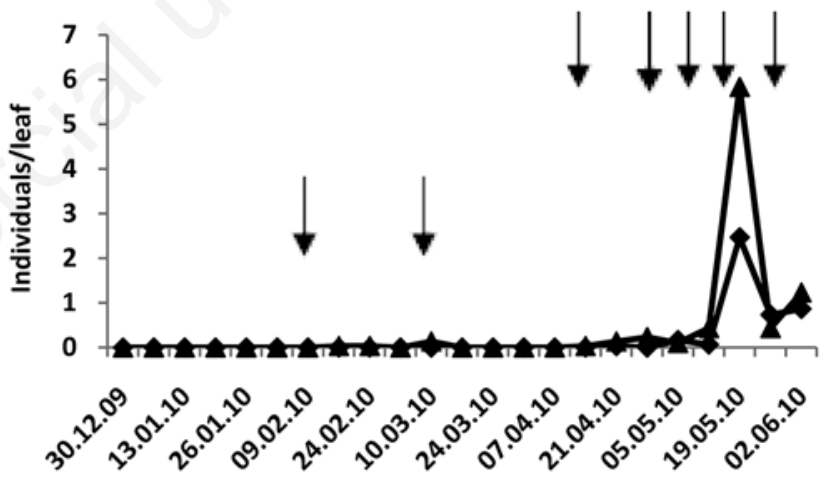

Figure 4. Dynamics of juvenile instars of Tuta absoluta in greenhouses $T(A)$ and $P(B) .(\downarrow)$ indicates Bt sprays.

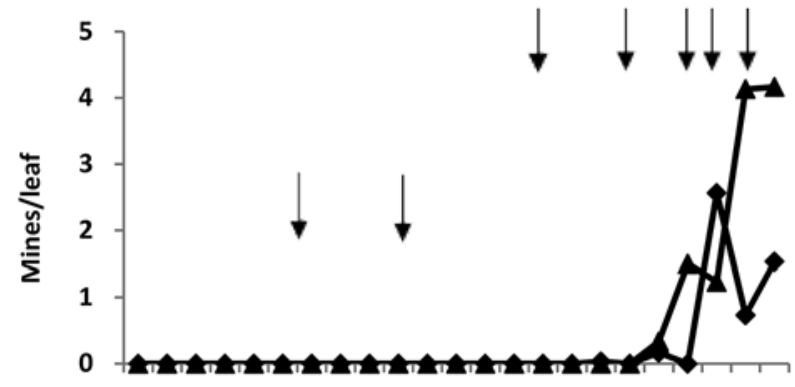

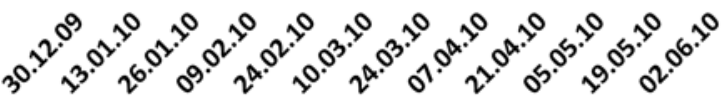

$\longrightarrow$ Greenhouse T $\longrightarrow$ Greenhouse P
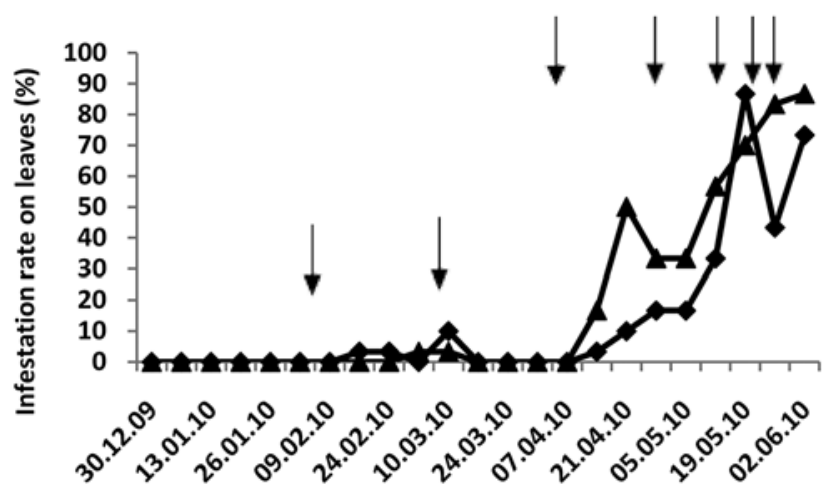

A

$\longrightarrow$ Greenhouse T $\longrightarrow$ Greenhouse P

Figure 5. Mean number of larval galleries of Tuta absoluta per leaf (A) and infestation rate of leaves (B) in greenhouses $T$ and $P$. ( $\downarrow$ ) indicates Bt sprays. 
gradually to reach a maximum of 9.7 individuals per leaf on $26^{\text {th }}$ May 2010 in greenhouse $T$ and 8.3 individuals per leaf on $19^{\text {th }}$ May 2010 in greenhouse $P$ (Figure $4 \mathrm{~A}$ and $\mathrm{B}$ ). This high population density caused infestation rates on leaves on $2^{\text {nd }}$ June 2010 in both greenhouses (Figure 5B). Similarly, the number of mines per leaf remained low until April, then increased progressively to reach a maximum of 4.2 mines per leaf on $2^{\text {nd }}$ June 2010 in greenhouse $T$ and 2.6 mines per leaf on $19^{\text {th }}$ May 2010 in greenhouse $P$ (Figure 5B).

\section{Estimation of tomato fruit loss}

The assessment of fruit losses started on 28 April 2010 until the end of the trial. The fruit infestation rate remained low in the beginning with a maximum of $2 \%$ in both greenhouses. The final infestation rates were $4.3 \%$ and $11 \%$ in greenhouses $T$ and $P$, respectively without a significant difference (t-test, $\mathrm{P}>0.05$ ) (Figure 6).

\section{Impact of insect-proof net on plant growth and quality of tomato fruits}

\section{Impact on plant growth}

Measurement of tomato plants height from day 100 to day 142 after transplantation showed that plants have the same growth speed without significant differences (t-test, all $\mathrm{P}>0.05$ ) (Figure 7A). The mean growth rate \pm standard error (SE) was $2.5 \pm 0.21 \mathrm{~cm} /$ day in greenhouse $T$ and $2.7 \pm 0.14 \mathrm{~cm} /$ day in greenhouse $P$. Similarly, stems' diameters were not significantly different (t-test, all $\mathrm{P}>0.05$ ). The average diameter $\pm \mathrm{SE}$ of the stems increased from $1.6 \pm 0.19$ to $1.7 \pm 0.25 \mathrm{~cm}$ after 42 days in greenhouse $T$ and from $1.6 \pm 0.22$ to $1.8 \pm 0.25 \mathrm{~cm}$ in greenhouse $P$ during the same period (Figure 7B).

On the other hand, the average height of the first bunch showed no significant differences between studied greenhouses (t-test, $\mathrm{P}=0.11>0.05$ ). Indeed, for 100 -day aged plants, the average height \pm SE of the first bunch was about $26.3 \pm 2.46 \mathrm{~cm}$ in greenhouse $T$ and $28.8 \pm 4.64 \mathrm{~cm}$ in greenhouse $P$ (Figure 7C).

\section{Impact on tomato fruit quality}

The pattern of tomato fruit firmness during ripening was similar in both studied greenhouses was similar. It decreased from the first ripening stage (turning) to the fourth ripening stage (red-ripe) from an average of $3.46 \mathrm{~kg} / \mathrm{cm}^{2}$ to $1.15 \mathrm{~kg} / \mathrm{cm}^{2}$ respectively without significant differences between greenhouses $T$ and $P$ within each ripening stage (t-test, all $\mathrm{P}>0.05$ ) (Figure 8A).

The $\mathrm{pH}$ of tomato juice does not reflect its concentration in acids and

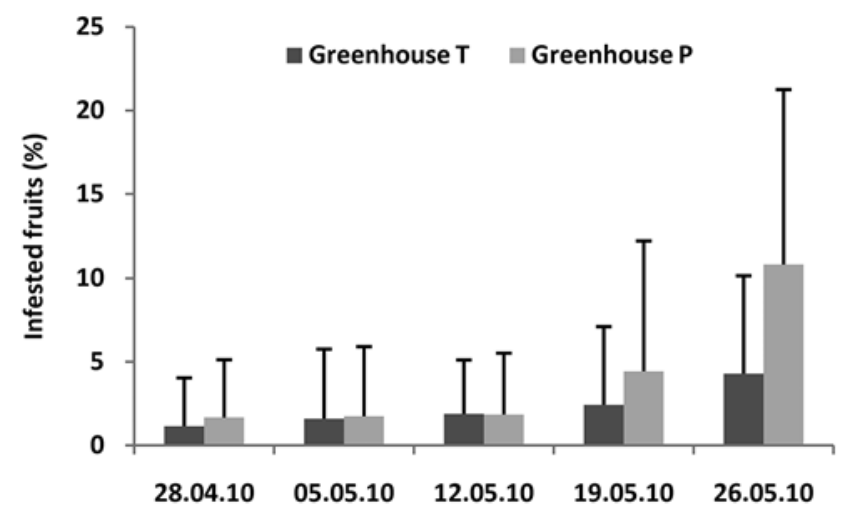

Figure 6. Percentage of fruits infested by Tuta absoluta in the experimental greenhouses. is generally between 4 and 4.5 (Grasselly et al., 2000). In this study, the $\mathrm{pH}$ was between 4.01 and 4.16 in the greenhouse $T$ and between 4.02 and 4.14 in greenhouse $P$ (Figure $8 \mathrm{~B}$ ), without significant difference between greenhouses $T$ and $P$ within each ripening stage (t-test, all $\mathrm{P}>0.05)$.

TSS as measured by the refractometric index increased in greenhouse $P$ from $4.08^{\circ} \mathrm{Brix}$ in the turning stage to $4.27^{\circ} \mathrm{Brix}$ in the red-ripe stage (Figure $8 \mathrm{C}$ ). In greenhouse $T$, it decreased from $4.11^{\circ}$ Brix in the turning stage to $3.69^{\circ}$ Brix in the red-ripe stage while marking a slight increase at pink stage reaching $4.13^{\circ}$ Brix. TSS at red-ripening stage was significantly higher in greenhouse $P$ than on greenhouse $T$ (t test, $\mathrm{P}=0.03$ ) (Figure 8C).
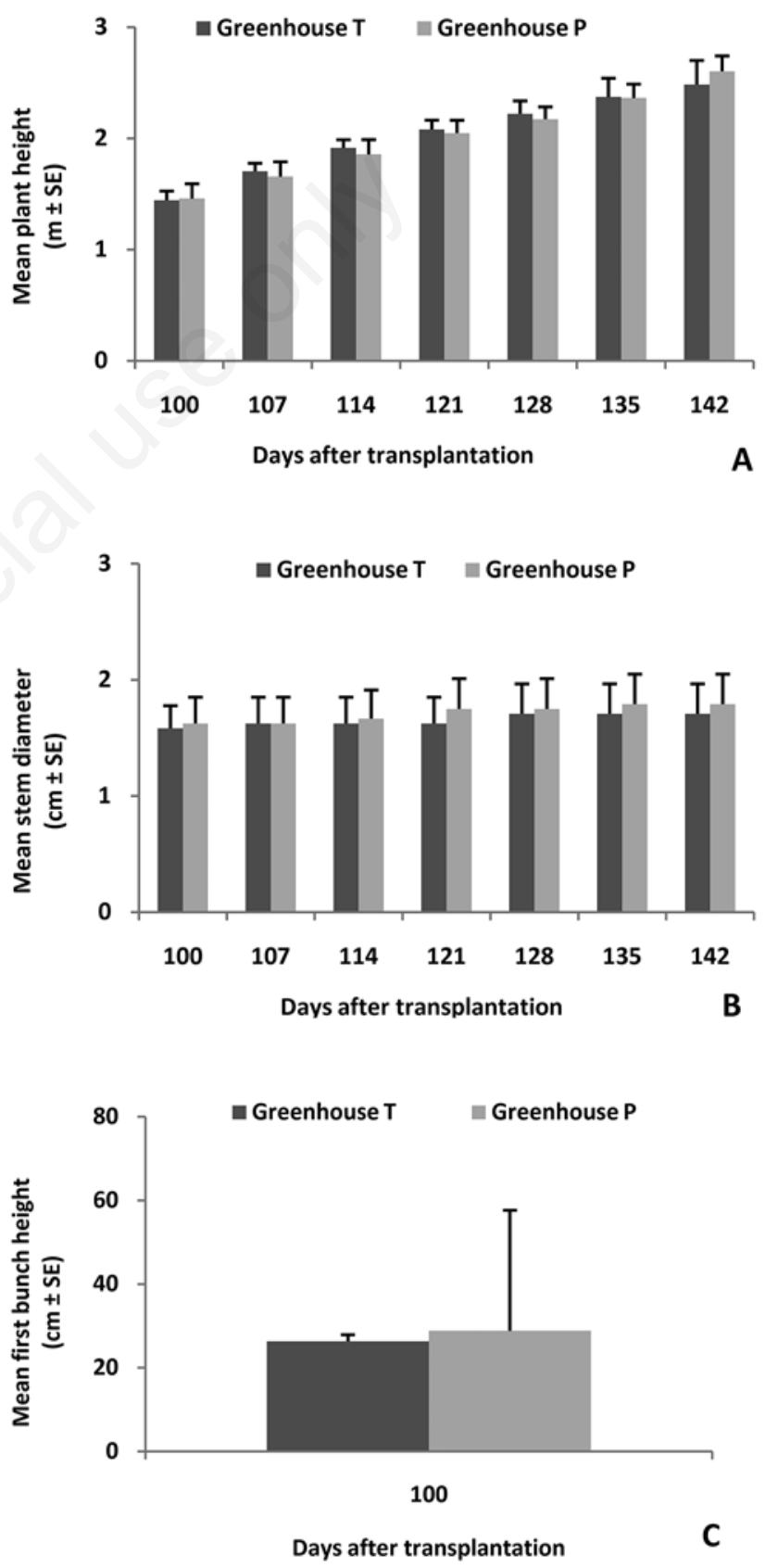

Figure 7. Tomato growth parameters in experimental greenhouses: plant height $(\AA)$; plant diameter (B) and height of the first bunch $(\mathrm{C})$. 
TA represented by the citric acid content, showed the same pattern as the TSS with a maximum of $4.54 \mathrm{~g} / \mathrm{L}$ and $4.76 \mathrm{~g} / \mathrm{L}$ and a minimum of 3.52 $\mathrm{g} / \mathrm{L}$ and $4.14 \mathrm{~g} / \mathrm{L}$ in greenhouses $T$ and $P$, respectively without a significant differences in all ripening stage (t-test, all $\mathrm{P}>0.05$ ) (Figure 8D).

The dry matter (DM) in tomato fruits in greenhouse $T$ ranged from $5.67 \%$ in the turning stage to $5.15 \%$ in the red-ripe stage (Figure $8 \mathrm{E}$ ). On the other hand, in greenhouse $P$ it decreased from $5.73 \%$ in the turning stage to $4.93 \%$ in the red-ripe stage (Figure $8 \mathrm{E}$ ) without significant differences (t-test, all $P>0.05$ ). Considering that tomato fruits in greenhouse $P$ had in the red-ripe stage higher TSS than those of the greenhouse $T$, the average fruit weight in the first greenhouse $(89.17 \mathrm{~g})$ was higher than that recorded in greenhouse $T(63.94 \mathrm{~g})$, even though no significant difference was observed (t-test, $\mathrm{P}=0.284$ ) (Figure $8 \mathrm{~F}$ ).

\section{Discussion and conclusions}

Measurements of air temperature and relative humidity in tomato greenhouses with different netting modalities revealed similar climatic
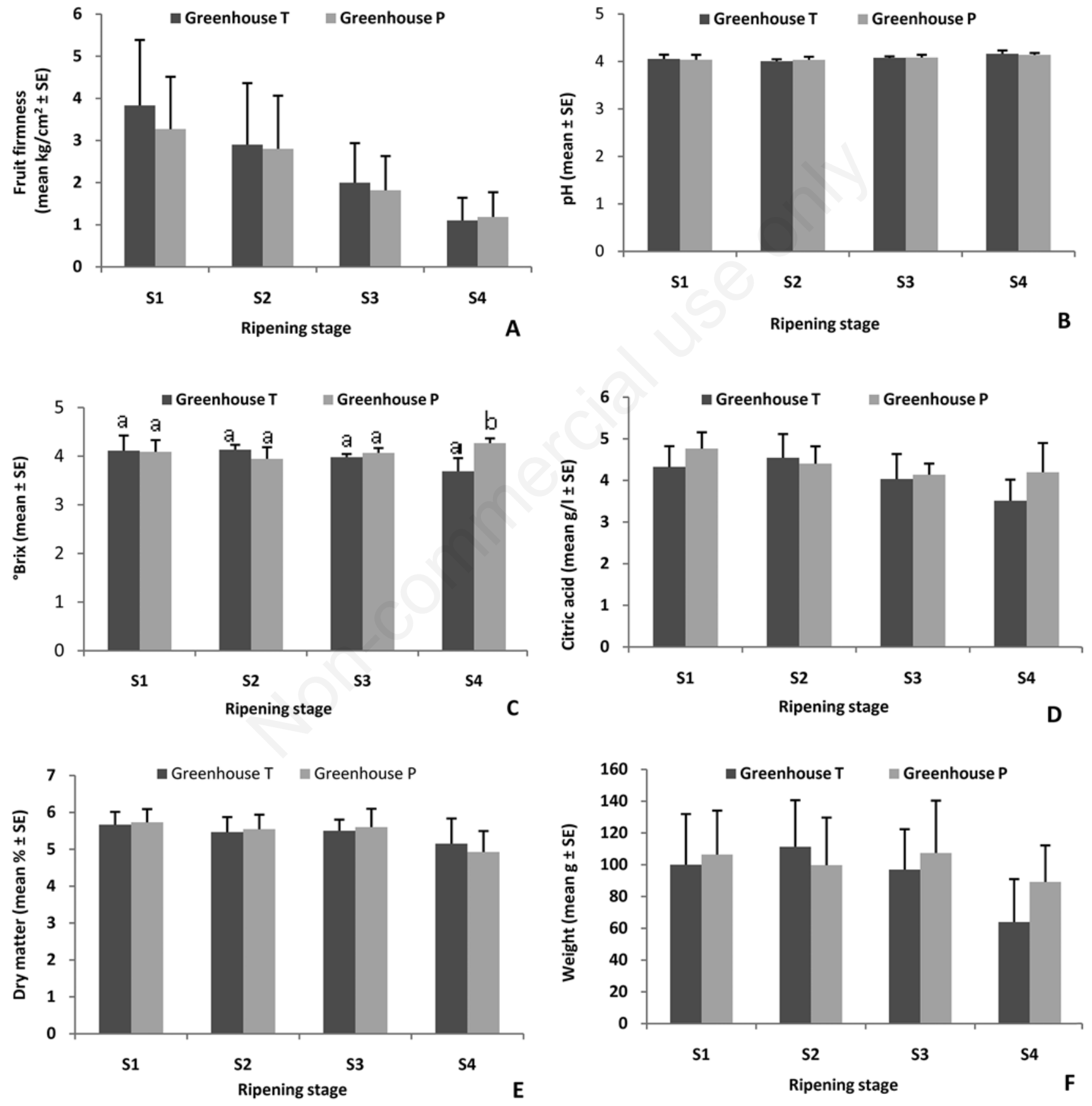

Figure 8. Mean ( \pm SE) tomato quality parameters values in the greenhouses $T$ and $P$. A) Firmness; B) pH (B); C) total soluble solid; D) titrable acidity; E) dry matter; F) weight. Ripening stages: turning (S1); pink (S2); light-red (S3); red-ripe (S4). Means within each ripening stage marked with different letters are significantly different by t-test $(P<0.05)$. 
conditions. This can be explained by the same percentage of aeration. However, it may also depend on the physical properties of the insectproof nets used such as transmissivity (the ability to transmit radiation) and reflectivity (the ability to reflect radiation). As a general rule, nets are non uniform materials and the effect of their radiometric properties on the crops should be taken into consideration. On the other hand, despite the netting of the experimental greenhouses, T. absoluta infested the studied crops even though the number of leaf mines and fruit damage were relatively low.

Furthermore, Bt-based insecticides specifically targeting T. absoluta were applied 7 times during the cropping season which reduced the density of larvae on leaves and the infestations on leaves and fruits. However, repeated sprayings of Bt without alternating insecticides with different active ingredients and modes of action can result in emergence of Bt-resistant populations of T. absoluta (Braham et al., 2012). This was the case for many other lepidopteran pests such as Spodoptera frugiperda (J. E. Smith) and Helicoverpa armigera (Hübner) (Wu, 2007; Zhu et al., 2015).

The flight patterns of the males of T. absoluta captured in sex pheromone traps were comparable in studied greenhouses as well as the population dynamics of the pest and the infestation rates on leaves and fruits. These indicate that both tested insect-proof net setups can provide the same levels of protection against $T$. absoluta. In both cases, the integration of sex pheromone traps with insect-proof nets and $\mathrm{Bt}$ sprays resulted in a relatively low level of crop infestation. The early detection of the presence of adults of $T$. absoluta with pheromone traps may allow targeting first instar larvae known to be the most susceptible to Bt. This can be very effective in tackling early the pest as the following larval instars are endophytic and hard to be targeted with insecticides acting through contact or ingestion.

When combining sex pheromone trapping and insect proof nets, it is important to ensure that nets are well installed and holes-free and traps are well maintained (adjustment of the level of water for water traps or renewal of sticky boards in case of delta traps). Abbes and Chermiti (2011) reported that the use of pheromone traps without insect-proof net combined with bad trap maintenance can result in higher infestation rate by raising the density of males in the greenhouse and consequently the mating chances. However, in Tunisia, we noticed that during the achievement of some agricultural practices such as pruning and especially harvest, some growers open the greenhouses' doors allowing the increase of the imaginal populations of $T$. absoluta and by consequence leaf and fruit infestation rates especially towards the end of the cropping cycle.

Recent studies on the efficiency of $\alpha$-cypermethrin-treated nets reported their potential to prevent the entrance of adults of $T$. absoluta inside the greenhouses through their repellence and long term side effects on pest life history parameters and reproductive fitness (Biondi et al., 2015). This can ameliorate the efficiency of insect-proof nets considering the combined effects of the physical barrier and the insecticide. Furthermore, some Tunisian growers prefer to maintain their netted tomato greenhouses closed even after the end of the cropping cycle in order to avoid the dissemination of the pest. This good agricultural practice can reduce the level of inoculum of $T$. absoluta in the next tomato cropping seasons (in greenhouses and open field) (Abbes et al., $2012 b)$. Thus, the use of $\alpha$-cypermethrin-treated nets can make this strategy more efficient in reducing the imaginal population of the pest.

In this study, similar plant growth parameters were registered in both greenhouses suggesting that the type of netting setups as described has no direct impact on the vegetative growth of tomato plant. In addition, most fruit quality parameters (firmness, pH, TA, DM and weight) were comparable under both tested cropping conditions. However, TSS was higher in the greenhouse equipped with insectproof nets in the aeration strips $P$ at the end of the study. This can be explained by the fact that netting the entire greenhouse can decrease the solar radiation which may result in the decrease of the TSS in the fruits especially near maturation (red-ripe ripening stage). This phenomenon is known as the shading factor which can vary according to the net material and colour (Castellano et al., 2008). These parameters should be also taken in consideration when using insect-poof nets.

Based on our findings, it can be concluded that the total netting of the greenhouses is not economically rewarding since the netting of openings can give the same level of protection against T. absoluta. This netting setup can be ameliorated by using insecticide-treated nets to enhance the role of the physical barrier.

\section{References}

ABBES K., CHERMITI B., 2011 - Comparison of two marks of sex pheromone dispenserscommercialized in Tunisia for their efficiency to monitor and to control by mass-trapping Tuta absoluta under greenhouses. - Tunisian J. Plant Prot. 6: 133-148.

ABBES K., CHERMITI B., 2014 - Propensity of three Tunisian populations of the tomato leafminer Tuta absoluta (Lepidoptera: Gelechiidae) for deuterotokous parthenogenetic reproduction. Afr. Entomol. 22: 538-544.

ABBES K., CHERMITI B., ONILLON J.C., 2012a - Un espoir pour contrer Tuta: Essai de lutte intégrée contre Tuta absoluta en culture de tomate plein champ dans la région de Kairouan, en Tunisie. Phytoma. 654: 8-10.

ABBES K., HARBI A., CHERMITI B., 2012b - The tomato leafminer Tuta absoluta (Meyrick) in Tunisia: current status and management strategies. - EPPO Bull. 42: 226-233.

BIONDI A., DESNEUX N., SISCARO G., ZAPPALÀ L., 2012a - Using organic-certified rather than synthetic pesticides may not be safer for biological control agents: Selectivity and side effects of 14 pesticides on the predator Orius laevigatus. - Chemosphere 87: 803-812.

BIONDI A., MOMMAERTS V., SMAGGHE G., VIÑUELA E., ZAPPALÀ L., DESNEUX N., 2012b - The non-target impact of spinosyns on beneficial arthropods. - Pest Manage. Sci. 68: 1523.

BIONDI A., ZAPPALÀ L., DESNEUX N., APARO A., SISCARO G., RAPISARDA C., MARTIN T., TROPEA GARZIA G., 2015 - Potential toxicity of $\alpha$-cypermethrin-treated nets on Tuta absoluta (Lepidoptera: Gelechiidae). - J. Econ. Entomol. 108: 1-7.

BIONDI A., ZAPPALÀ L., STARK J.D., DESNEUX N., 2013 - Do biopesticides affect the demographic traits of a parasitoid wasp and its biocontrol services through sublethal effects? PLoS One 8: e76548.

BRAHAM M., GLIDA G.H., HAJJI L., 2012 - Management of the tomato borer, Tuta absoluta in Tunisia with novel insecticides and plant extracts. - EPPO Bull. 42: 291-296.

BRÉVAULT T., SYLLA S., DIATTE M., BERNADAS G., DIARRA K. 2014 Tuta absoluta meyrick (Lepidoptera: Gelechiidae): a new threat to tomato production in Sub-Saharan Africa. - Afr. Entomol. 22: 441-444.

CALIMAN F.R.B, DA SILVA D.J.H., STRINGHETA P.C., FONTES P.C.R., MOREIRA G.R, MANTOVANI E.C., 2010 - Quality of tomatoes grown under a protected environment and field conditions. Idesia 28: 75-82.

CARVALHO G.A., REIS P.R., ROCHA L.C.D., MORAES J., FUINI L., ECOLE C., 2003 - Side-effects of insecticides used in tomato fields on Trichogramma pretiosum (Hymenoptera, Trichogrammatidae). Acta Scient. Agron. 25: 275-279.

CASTELLANO S., SCARASCIA MUGNOZZA G., RUSSO G., BRIASSOULIS D., MISTRIOTIS A., HEMMING S., WAAIJENBERG D., 2008 - Plastic nets in agriculture: a general review of types and applications. Appl. Engine. Agric. 24: 799-808.

CHERMITI B., ABBES K., AOUN M., BEN OTHMANE S., OUHIBI M., GAMOON W., KACEM S., 2009 - First estimate of the damage of 
Tuta absoluta (Povolny) (Lepidoptera: Gelecheiidae) and evaluation of the efficiency of sex pheromone traps in greenhouses of tomato crops in the Bekalta region, Tunisia.- Afr. J. Plant Sci. Biotechnol. 3: 49-52.

COCCO A., DELIPERI S., DELRIO G., 2013 - Control of Tuta absoluta (Meyrick) (Lepidoptera: Gelechiidae) in greenhouse tomato crops using the mating disruption technique. - J. Appl. Entomol. 137: 16-28.

DESNEUX N., LUNA M., GUILLEMAUD T., URBANEJA A., 2011 -The invasive South American tomato pinworm, Tuta absoluta, continues to spread in Afro-Eurasia and beyond: the new threat to tomato world production. - J. Pest Sci. 84: 403-408.

DESNEUX N., WAJNBERG E., WYCKHUYS K.A.G., BURGIO G., ARPAIA S., NARVÁEZ-VASQUEZ C.A., GONZÁLEZ-CABRERA J., CATALÁN RUESCAS D., TABONE E., FRANDON J., PIZZOL J., PONCET C., CABELLO T., URBANEJA A., 2010 - Biological invasion of European tomato crops by Tuta absoluta: ecology, geographic expansion and prospects for biological control. - J. Pest Sci. 83: 197-215.

GRASSELLY D., NAVEZ B., LETARD M., 2000 - Tomate, pour un produit de qualité. - Centre Technique Interprofessionel des fruits et Légumes, Paris: $222 \mathrm{pp}$.

GRAVENA S., 1991 - Manejo integrado de pragas do tomateiro. In: Anais do $2^{\circ}$ Encontro Nacional de Produção e Abastecimento de Tomate, 8-11 October, Jaboticabal, Brazil: 105-157.

GUEDES R.N.C., PICANÇO M.C., 2012 - The tomato borer Tuta absoluta in South America: pest status, management and insecticide resistance. - EPPO Bull. 42: 211-216.

GUENAOUI Y., 2008 - Nouveau ravageur de la tomate en Algérie: Première observation de Tuta absoluta, mineuse de la tomate invasive, dans la region de Mostaganem, au printemps 2008. - Phytoma. 617: 18-19

HADDI K., BERGER M., BIELZA P., CIFUENTES D., FIELD L.M., GORMAN K., RAPISARDA C., WILLIAMSON M.S., BASS C., 2012 Identification of mutations associated with pyrethroid resistance in the voltage-gated sodium channel of the tomato leaf miner (Tuta absoluta). - Insect Biochem. Mol. Biol. 42: 506-513.

HARBI A., ABBES K., CHERMITI B., 2012 - Evaluation of two methods for the protection of tomato crops against the tomato leafminer Tuta absoluta (Meyrick) under greenhouses in Tunisia. - EPPO Bull. 42: 317-321.

LEBDI G. K., SKANDER M., MHAFDHI M., BELHADJ R., 2011- Lutte intégrée contre la mineuse de la tomate, Tuta absoluta Meyrick (Lepidoptera: Gelechiidae) en Tunisie. - Faunistic Entomol. 2011: 125-132.

LEITE G.L.D., PICANÇO M., LUCIA T.M.C., DELLA MOREIRA M.D.,1999 - Role of canopy height in the resistance of Lycopersicon hirsutum f. glabratum to Tuta absoluta (Lep., Gelechiidae). - J. Appl. Entomol. 123: 459-463.

MEGIDO R.C., BROSTAUX Y., HAUBRUGE E., VERHEGGEN F., 2013a Propensity of the tomato leafminer, Tuta absoluta (Lepidoptera:
Gelechiidae), to develop on four potato plant varieties. - Am. J. Potato Res. 90: 255-260.

MEGIDO R.C., HAUBRUGE E., VERHEGGEN F.J., 2012 - First evidence of deuterotokous parthenogenesis in the tomato leafminer, Tuta absoluta (Meyrick) (Lepidoptera: Gelechiidae). - J. Pest Sci. 85: 409-412.

MEGIDO R.C., HAUBRUGE E., VERHEGGEN F.O., 2013b - Pheromonebased management strategies to control the tomato leafminer, Tuta absoluta (Lepidoptera: Gelechiidae). - Biotechnologie, Agronomie, Société et Environnement 17: 475-482.

MOLLÁ 0., GONZÁLEZ-CABRERA J., URBANEJA A., 2011 - The combined use of Bacillus thuringiensis and Nesidiocoris tenuis against the tomato borer Tuta absoluta. - BioControl 56: 883-891.

RODITAKIS E., VASAKIS E., GRISPOU M., STAVRAKAKI M., NAUEN R., GRAVOUIL M., BASSI A., 2015 - First report of Tuta absoluta resistance to diamide insecticides. - J. Pest Sci. 88: 9-16.

SILVA C.C., JHAM G.N., PICANÇO M., LEITE G.L.D., 1998 - Comparison of leaf chemical compositionand attack patterns of Tuta absoluta (Meyrick) (Lepidoptera: Gelechiidae) in three tomato species. Agron. Lusitana 46: 61- 71.

SIQUEIRA H.A.A., GUEDES R.N.C., FRAGOSO D.B., MAGALHAES L.C., 2001 -Abamectin resistance and synergism in Brazilian populations of Tuta absoluta (Meyrick) (Lepidoptera : Gelechiidae). - Int. J. Pest Manage. 47: 247-251.

TEITEL M., 2006 - The effect of screens on the microclimate of greenhouses and screenhouses - a review. - Acta Hortic. 719: 575-586.

TROPEA GARZIA G., SISCARO G., BIONDI A., ZAPPALÀ L., 2012 - Tuta absoluta, a South American pest of tomato now in the EPPO region: biology, distribution and damage. - EPPO Bull. 42: 205-210.

URBANEJA A., VERCHER R., NAVARRO V., GARCÍA MARÍ F., PORCUNA J.L., 2007 - La polilla del tomate," Tuta absoluta". - Phytoma Espana 194: 16-23.

VALERA D., ÁLVAREZ A., MOLINA F., 2006 - Aerodynamic analysis of several insect-proof screens used in greenhouses. - Spanish J. Agric. Res. 4: 273-279.

VISKELIS P., JANKAUSKIENE J., BOBINAITE R., 2008 - Content of carotenoids and physical properties of tomatoes harvested at different ripening stages. - In: Foodbalt, 3rd Baltic Conference on Food Science and Technology, Jelgava, Latvia: 166-170

WU K., 2007 - Monitoring and management strategy for Helicoverpa armigera resistance to Bt cotton in China. - J. Invert. Pathol. 95: 220-223.

WUZHONG N., 2002 - Yield and quality of fruits of solanaceous crops as affected by potassium fertilization. - Better Crop. Int. 16: 6-8.

ZHU Y.C., BLANCO C.A., PORTILLA M., ADAMCZYK J., LUTTRELL R., HUANG F., 2015 - Evidence of multiple/cross resistance to Bt and organophosphate insecticides in Puerto Rico population of the fall armyworm, Spodoptera frugiperda. - Pest. Biochem. Physiol. 122: 15-21. 